\title{
ANALYSIS OF TAX BURDEN AND THE RELEVANCE OF GOVERNMENT REGULATION NUMBER 23 YEAR 2018 TO MICRO, SMALL, AND MEDIUM ENTERPRISES
}

\author{
Muhammad Alfiyan \\ [Pegawai Direktorat Jenderal Pajak, Kementerian Keuangan RI] \\ Nur Arif Nugraha \\ [Politeknik Keuangan Negara STAN] \\ Alamat Korespondensi: [nur.nugraha@pknstan.ac.id]
}

INFORMASI ARTIKEL
Diterima Pertama
[18112021]
Dinyatakan Diterima
[23112021]
KATA KUNCl:
PP 23 Tahun 2018, UMKM, beban pajak, tarif pajak,
keadilan pajak

KLASIFIKASI JEL:

$\mathrm{H} 2 \mathrm{O}$

\section{ABSTRAK}

The purpose of this study is to provide views of the implementation of the Government Regulation Number 23 Year 2018 (PP 23 of 2018) from the aspect of the tax burden. In the previous regulation, the equity principle actually contradicts the simplicity offered by the Government Regulation Number 46 Year 2013 (PP 46 of 2013). This is because PP 46 of 2013 imposes final income tax on the basis of taxation in the form of gross turnover. How does the government deal with this through PP 23 of 2018? Is PP 23 of 2018 relevant to be applied for MSMEs? The method used in this paper is descriptive by conducting comparative analysis. The results of the study concluded that PP 23 of 2018 provides more opportunities for MSMEs to get tax incentives. In addition, PP 23 of 2018 is also more relevant in eroding the informal economy sector in Micro, Small, Medium Enterprises (MSMEs). PP 23 of 2018 allows MSMEs to use general tax rate in article 17 of Income Tax Law and MSMEs that used PP 23 of 2018 are given a certain period of time so that MSMEs cannot always employ PP 23 of 2018. Therefore, this regulation needs to include dissemination related to bookkeeping and tax administration for MSMEs. Thus, the policy related to PP 23 of 2018 is correct. The results of this study are expected to be beneficial for the government, especially the Directorate General of Taxes.

Tujuan penelitian ini adalah untuk memberikan pandangan terkait pelaksanaan PP 23 Tahun 2018 dari aspek beban pajak. Dalam peraturan pendahulunya, prinsip keadilan nyatanya bertentangan dengan kemudahan yang ditawarkan oleh PP 46 Tahun 2013. Hal tersebut karena PP 46 tahun 2013 mengenakan pajak penghasilan secara final dengan dasar pengenaan pajak berupa peredaran bruto. Bagaimana pemerintah menyiasati hal tersebut melalui PP 23 Tahun 2018? Apakah PP 23 Tahun 2018 relevan untuk diterapkan pada UMKM? Metode yang digunakan adalah deskriptif dengan melakukan analisis komparasi. Hasil penelitian menyatakan bahwa PP 23 Tahun 2018 memberikan kesempatan yang lebih banyak untuk UMKM mendapatkan insentif pajak. Selain itu, PP 23 tahun 2018 juga lebih relevan dalam mengikis sektor ekonomi informal pada UMKM. PP 23 Tahun 2018 memperbolehkan UMKM untuk menggunakan tarif umum Pasal 17 UU PPh dan bagi UMKM yang menggunakan PP 23 Tahun 2018 diberikan jangka waktu tertentu sehingga tidak selamanya UMKM dapat menggunakan PP 23 Tahun 2018. Oleh karena itu, peraturan ini perlu diikuti dengan sosialiasasi terkait pembukuan dan administrasi perpajakan kepada UMKM. Dengan demikian, kebijakan terkait PP 23 Tahun 2008 sudah tepat. Hasil Penelitian ini diharapkan dapat menjadi masukan kepada pemerintah khususnya Direktorat Jenderal Pajak. 


\section{INTRODUCTION}

MSMEs (micro, small and medium enterprises) have a crucial role as a driving force of the Indonesian economy (BPS, 2019). Based on data from the Ministry of Cooperatives and SMEs, the number of MSME units from 2013 to 2019 continued to increase. This amount reaches $99.99 \%$ of the total number of business units in Indonesia. MSMEs were also able to absorb as many as 119 million workers or around $96 \%$ of the total workforce in all business units in 2019. In addition, the contribution of MSMEs to gross domestic product (GDP) over the last three years exceeded 60 percent of the total GDP in Indonesia.

Table 1. Micro, Small, and Medium Enterprises Management (MSME) Data in 2016

\begin{tabular}{llcc}
\hline No. MSME Management & No (\%) & $\begin{array}{l}\text { Yes } \\
\text { (\%) }\end{array}$ \\
\hline 1. & $\begin{array}{l}\text { Legal entities or special } \\
\text { licence }\end{array}$ & 93,45 & 6,55 \\
2. $\quad \begin{array}{l}\text { Financial statement } \\
\text { creation }\end{array}$ & 92,48 & 7,52 \\
3. Use of the computer & 93,78 & 6,22 \\
4. Use of the internet & 90,24 & 9,76 \\
\hline
\end{tabular}

Source: Badan Pusat Statistik (2019)

Table 1 describes the management of micro and small enterprises in Indonesia, such as legal entities, financial statement, and use of technology. Most of them have informal characteristics and are managed simply. Simple management is reflected in the majority of micro and small businesses that do not make financial reports and make little use of technology. In addition, the small number of micro and small businesses that are legal entities or have business licenses means that most of them are still in the informal sector (BPS, 2019). These become a challenge for the Directorate General of Taxes (DGT) to be able to include MSMEs in the tax system, by requiring them to register and pay taxes.

The existence of MSMEs in the informal sector has become a concern in tax reform in Indonesia. This is marked by the rule of calculating norms which has a simpler tax imposition (Kristiaji \& Mukarromah, 2020). 2020). Then, this was followed by the existence of a presumptive tax regime through PP-46/2013 (Government Regulation Number 46 of 2013). In the regulation, taxpayers who generate a certain gross turnover ( 4.8 billion rupiahs) only need to calculate their gross turnover and then multiply it by the $1 \%$ rate to calculate the tax payable. However, the imposition of final income tax through PP-46/2013 is considered unfair. This is because gross turnover does not necessarily reflect the benefits obtained by taxpayers (Suyani, 2017). In addition, the $1 \%$ rate is considered too burdensome for taxpayers (Hadiprajitno \& Zulaikha, 2016).

In mid-2018, PP-46/2013 was revoked and replaced with PP-23/2018 (Government Regulation Number 23 of 2018 concerning Income Tax on Income from Businesses Received or Gained by Taxpayers with Certain Gross Revenue). This regulation has several changes from PP-46/2013, including a reduction in the tariff to $0.5 \%$, a certain period of time, and the provision of options for taxation. Such changes aim to provide a fairer tax burden and ease the taxes that must be paid so that MSME actors can develop their businesses.

The importance of the role of MSMEs and the unfairness of the tax burden for MSMEs in PP-46/2013 attracted the interest of researchers to analyze the replacement regulation, namely PP-23/2018. This study intends to find out how the structure of the tax burden in imposing taxes on MSMEs through PP-23/2018 and whether PP-23/2018 is relevant to the characteristics of MSMEs in Indonesia which tend to be in informal sectors rather than formal sectors.

\section{LITERATURE REVIEW}

\section{Equity Principle}

The principle of equity (Smith, 1776) has introduced a tax concept that is still relevant until today, namely the principle of ability to pay. Under that principle, taxpayers with higher incomes have the ability to pay greater than those with lower incomes. Musgrave describes the ability to pay principle as fulfilling horizontal equity and vertical equity (Repetti \& McDaniel, 1993). Kabinga (2016) explains that horizontal justice is related to equal treatment for taxpayers in the same circumstances, while vertical justice explains that the greater a person's income, the higher the tax charged must be. This is applied in the imposition of taxes on individuals with progressive rates based on Article 17 paragraph (1) letter a of Income Tax Law.

\section{Income Tax}

The most basic characteristic of income tax is that income tax is subjective. The subjective meaning is that the imposition of taxes begins with determining the subject first, after which the objective conditions will be met. The condition of the tax subject will greatly determine the imposition of the tax (Purwanto, 2014).

Purwanto (2014) explains that the subjective nature of income tax is closely related to the theory of carrying force, namely the imposition of taxes must be based on the ability to pay of the subject. With a unidirectional view, Anggara (2016) relates the principle of carrying style to the individual's basic needs or primary needs that must be met before being taxed. Both agree that the principle of carrying style is not only based on income factors, but also on primary needs and dependents.

Many income tax systems allow the exemption of individuals and family members as income deductions. This deduction is usually based on the number of families and possibly family characteristics (Stotsky, 1999). Tax regulations in Indonesia also regulate similarly. Article 6 paragraph (3) of the Income Tax Law (Income Law) allows income deduction, named nontaxable income or personal allowances (certain amount of deduction for individuals and family members). The amount of PTKP refers to the Regulation of the Minister of Finance Number 101/PMK.010/2016. 


\section{Previous Research}

Several countries have used presumptive taxes to tax the MSME sector, such as Uganda (Verberne, 2018), Rwanda (Eissa \& Zeitlin, 2017), and Indonesia (Aditya, 2020). Presumptive tax is an imposition scheme that uses an alternative tax base that is different from the imposition of the general tax regime. Presumptive tax is generally applied to tax subjects with inadequate accounting skills. PP-46/2013 and PP$23 / 2018$ are presumptive tax implementations in Indonesia that use the tax base in the form of gross turnover.

Aditya (2020) proves that PP-46/2013 is able to increase taxpayer compliance which then increases the contribution of MSMEs to state revenues. This happens because the calculation of Income tax based on gross turnover is easier for MSMEs to carry out. However, research conducted by Suyani (2017) explains that gross revenue as DPP also breach the vertical and horizontal equity principle. PP-46/2013 was finally replaced with PP-23/2018.

In PP-23/2018, the rate imposed on taxpayers is reduced to $0.5 \%$ of gross turnover. The reduction in tariffs is expected to ease the tax burden that must be borne so that MSME actors can develop their businesses (Directorate General of Taxes, 2019). However, Aneswari's research (2018) states that the final $0.5 \%$ tariff still does not provide incentives for MSME actors because the regulation does not reflect the ability to pay and violates the basic right to obtain PTKP. It is inevitable that the presumptive tax is indeed easier for MSMEs to contribute to state revenues. The obstacle is that the final tax imposition of the adopted gross revenue still cannot achieve fairness in the calculation of taxes even though the rate is lowered.

\section{RESEARCH METHOD}

This study uses a mixed descriptive research approach. The quantitative approach can provide a clear picture of the tax burden that must be borne by taxpayers. Calculation samples are taken from each level of gross turnover and different profit margins. A qualitative approach is used to look at other views that cannot be explained only through numerical calculations. This approach is carried out through a literature study with the object of research in the form of laws and regulations related to the imposition of income tax on MSMEs. Through a mixed approach, this research can provide accurate and comprehensive evidence of numerical-narrative data (Samsu, 2017). The analytical method used is comparative analysis. Comparative analysis was conducted to compare the provisions of taxation based on Article 17 paragraph (1) letter a, PP-46/2013, and PP-23/2018.

\section{RESULT}

From previous paragraphs about background, literature review, previous research, and method, the authors would like to discuss about the result of the research as follows:

\section{Structure of MSME Income Tax Burden \\ Table 2. Tax Payable of Each Gross Revenue and Profit Margin of Corporate Taxpayers (in million rupiahs)}

\begin{tabular}{|c|c|c|c|c|c|c|c|}
\hline \multirow{2}{*}{\multicolumn{2}{|c|}{ Gross Revenue }} & \multicolumn{6}{|c|}{ Profit Margin } \\
\hline & & $1 \%$ & $5 \%$ & $10 \%$ & $15 \%$ & $20 \%$ & $25 \%$ \\
\hline \multirow{6}{*}{$\begin{array}{r}\text { PP 23 } \\
(0,5 \% \text { x } \\
\text { omzet) }\end{array}$} & 800 & 4 & 4 & 4 & 4 & 4 & 4 \\
\hline & 1600 & 8 & 8 & 8 & 8 & 8 & \\
\hline & 2400 & 12 & 12 & 12 & 12 & 12 & 12 \\
\hline & 3200 & 16 & 16 & 16 & 16 & 16 & 16 \\
\hline & 4000 & 20 & 20 & 20 & 20 & 20 & 20 \\
\hline & 4800 & 24 & 24 & 24 & 24 & 24 & 24 \\
\hline \multirow{6}{*}{$\begin{array}{r}\text { PP } 46 \\
(1 \% x \\
\text { omzet) }\end{array}$} & 800 & 8 & 8 & 8 & 8 & 8 & \\
\hline & 1600 & 16 & 16 & 16 & 16 & 16 & 16 \\
\hline & 2400 & 24 & 24 & 24 & 24 & 24 & 24 \\
\hline & 3200 & 32 & 32 & 32 & 32 & 32 & 32 \\
\hline & 4000 & 40 & 40 & 40 & 40 & 40 & 40 \\
\hline & 4800 & 48 & 48 & 48 & 48 & 48 & 48 \\
\hline & 800 & 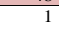 & 5 & 10 & 15 & 20 & 25 \\
\hline PPh Ps & 1600 & 2 & 10 & 0 & 30 & 40 & 50 \\
\hline & 2400 & 3 & 15 & 30 & 45 & 60 & 75 \\
\hline $\mathrm{xph}$ & 3200 & 4 & 20 & 40 & 60 & 80 & 100 \\
\hline \multirow[t]{2}{*}{ neto) } & 4000 & 5 & 25 & 50 & 75 & 100 & 125 \\
\hline & 4800 & 6 & 30 & 60 & 90 & 120 & 150 \\
\hline
\end{tabular}

Source: Simulated and processed by authors

Income on business of corporate taxpayers imposed under PP-46/2013 and PP-23/2018 results in different effective rates for each different level of profit margin. However, the effective rate for an entity is not determined by its gross turnover rate. The effective rate is the rate used to calculate the tax payable from net income. The effective rate is calculated using the following formula.

Effective rate $=($ tax payable: (gross income $\mathrm{x}$ margin)) $\times 100 \%$

The results obtained for PP-46/2013 are 1\% profit margin charged with $100 \%$ effective tariff and $10 \%$ profit margin charged with $10 \%$ effective tariff. The PP$46 / 2013$ rate will result in an effective tax rate equal to the Article 17 rate if the profit margin is $8 \%$.

The results obtained for PP-23/2018 are $1 \%$ profit margin charged with $50 \%$ effective rate and $10 \%$ profit margin charged with $5 \%$ effective tax rate. The PP$23 / 2018$ rate will result in an effective tax rate equal to the Article 17 rate if the profit margin is $4 \%$.

Gross turnover as a tax base may result in a higher tax burden than Article 17 for entities with lower profit margins and a lower tax burden than Article 17 for entities with higher profit margins. This is certainly in contrast to the principle of vertical justice described by Kabinga (2016), namely those with high incomes are expected to pay a larger percentage of their income in the form of taxes than those with low incomes. Even so, PP-23/2018 provides a lower tax burden than PP$46 / 2013$ so it has more opportunities to provide incentives to MSMEs that use this rule. 
Table 3. Tax Payable of Each Gross Revenue and Profit Margin from Individual Taxpayers (in million rupiahs)

\begin{tabular}{rrrrrrrr}
\hline \multirow{2}{*}{ Gross Revenue } & \multicolumn{7}{c}{ Profit Margin } \\
\cline { 2 - 8 } & & $\mathbf{1 \%}$ & \multicolumn{1}{c}{$\mathbf{5 \%}$} & $\mathbf{1 0 \%}$ & $\mathbf{1 5 \%}$ & $\mathbf{2 0 \%}$ & $\mathbf{2 5 \%}$ \\
\hline PP 23 & 1600 & 4 & 4 & 4 & 4 & 4 & 4 \\
$(0,5 \%$ x & 2400 & 12 & 12 & 12 & 12 & 12 & 8 \\
omzet) & 3200 & 16 & 16 & 16 & 16 & 16 & 12 \\
& 4000 & 20 & 20 & 20 & 20 & 20 & 20 \\
& 4800 & 24 & 24 & 24 & 24 & 24 & 24 \\
\hline & 800 & 8 & 8 & 8 & 8 & 8 & 8 \\
PP 46 & 1600 & 16 & 16 & 16 & 16 & 16 & 16 \\
$(1 \%$ x & 2400 & 24 & 24 & 24 & 24 & 24 & 24 \\
omzet) & 3200 & 32 & 32 & 32 & 32 & 32 & 32 \\
& 4000 & 40 & 40 & 40 & 40 & 40 & 40 \\
& 4800 & 48 & 48 & 48 & 48 & 48 & 48 \\
\hline & 800 & 0 & 0 & 0,4 & 2,4 & 8,2 & 14,2 \\
PPh Ps & 1600 & 0 & 0,4 & 8,2 & 20,2 & 32,2 & 52 \\
17 (25\% & 2400 & 0 & 2,4 & 20,2 & 42 & 72 & 103,4 \\
X ph & 3200 & 0 & 8,2 & 32,2 & 72 & 115,4 & 163,4 \\
neto) & 4000 & 0 & 14,2 & 52 & 528 & 163,4 & 223,4 \\
& 4800 & 0 & 20,2 & 72 & 648 & 211,4 & 283,4 \\
\hline
\end{tabular}

Source: Simulated and processed by authors

In contrast to corporations, the gross turnover of businesses run by individual taxpayers determines the calculation of the effective rate. The calculation of tax payable based on PP-46/2013, PP-23/2018 and Article 17 in this study uses two assumptions. The first assumption is that individual taxpayers only carry out business activities and do not have income from other sources which are included in the object of Article 4 paragraph (1) of the Income Tax Law. The second assumption is that PTKP is applied with the status of a married taxpayer and three dependents amounting to Rp72 million. The 25 percent tax rate is used to reflect the maximum taxable income layer applied to individual taxpayers.

Opportunities to obtain incentives in PP-23/2018 and PP-46/2013 are more limited for individual taxpayers than corporate taxpayers. With a gross turnover rate of 4.8 billion rupiah and a profit margin of $5 \%$, PP-23/2018 still provides a higher tax burden than the rate of article 17 . With a profit margin of $25 \%$, MSMEs run by individuals must have a turnover of at least Rp500 million so that the tax burden does not exceed the tax burden based on the tariff of Article 17. In addition, taxpayers who have a turnover of up to Rp. 300 million should not be subject to tax because the projected taxable income is still below the PTKP. The main factor in this happening is because regulation PP$23 / 2018$ does not include elements of PTKP in the regulation. This results in PP-23/2018 being imposed on every entrepreneur even those with a small turnover. Therefore, this regulation does not reflect the principle of carrying style which requires the fulfillment of a person's basic needs before being taxed on his income (Anggara, 2016).

\section{Income Tax Treatment for MSME in Indonesia}

In general, the taxation of income is based on net income. Net income is the amount of income received or earned by the taxpayer minus the allowable deductions as stated in Article 6 paragraph (1) of the Income Tax Law. The value generated from net income will be multiplied by the rate of Article 17 paragraph (1) letter a of the Income Tax Law so that the tax payable is obtained. Such income tax imposition system is known as the global taxation system (Kristiaji \& Mukarromah, 2020).

The global taxation system, which makes net income a determinant of the amount of tax to be paid, has implemented a fair tax collection system (Kristiaji \& Mukarromah, 2020). This is in accordance with the principle of equality introduced by Adam Smith, namely the distribution of the tax burden must be balanced with the income enjoyed, in this case net income (Zulvina et al., 2017). However, the global taxation system is known to be quite complicated in practice. Taxpayers must record their income and expenses and then make fiscal adjustments to the books that have been made to comply with existing tax regulations.

Article 28 paragraph (1) of the KUP Law obliges every taxpayer who carries out business activities to carry out bookkeeping. This obligation requires taxpayers who carry out business activities to understand bookkeeping with accounting standards applicable in Indonesia. Therefore, understanding accounting will affect taxpayer compliance (Pakpahan, 2015). However, the census conducted by BPS in 2016 provides the fact that more than $90 \%$ of micro and small businesses do not have special permits, do not make financial reports, do not use computers and the internet in running their business (BPS, 2019). When MSMEs were charged based on net income, tax revenue from MSMEs in 2011 was less than $0.5 \%$ of total tax revenues (Ibrahim, 2013).

Ibrahim (2013) stated that in order to improve the compliance of MSME taxpayers, the government issued PP-46/2013 which uses turnover as the basis for imposing taxes. The issuance of PP-46/2013 has certainly changed the way in which Income tax is imposed on MSMEs. In line with that, the results of Aditya (2020) proves that PP-46/2013 is able to increase taxpayer compliance which then increases the contribution of MSMEs to state revenue. This happens because the calculation of income tax based on turnover is easier for MSMEs to carry out.

Gross revenue is clearly stated as the basis for taxation based on PP-46/2013, so that MSMEs would still be subject to tax even though they do not book any profit. In her research, Suyani (2017) states that the imposition system creates injustice both horizontally and vertically. Taxpayers with low gross turnover and low profit margins will not get the incentives provided by PP-46/2013.

Taxpayers are allowed and required to use PP$46 / 2013$ if in the last tax year the gross turnover did not exceed Rp. 4.8 billion. This rule is certainly a setback for MSMEs, which before PP-46/2013 had kept the books (Endrianto, 2015), but they still had to use PP-46/2013. This requirement is certainly detrimental for taxpayers who have low profit margins or are in a state of loss. In addition, the criteria for taxpayers in PP-46/2013 resemble the criteria for taxpayers who can use NPPN, so that the issuance of PP-46/2013 creates overlapping rules.

The weakness of PP-46/2013 is the trigger for the government's evaluation to issue PP-23/2018. The 
majority of MSMEs do not understand bookkeeping and taxation, so PP-23/2018 still has the same concept of imposition of Income tax of PP-46/2013, namely the imposition based on gross turnover. However, the tariff for PP-23/2018 is lower than PP-46/2013, thus providing more opportunities for MSMEs to get incentives. In addition, taxpayers are allowed to choose between using PP-23/2018 or the imposition of Income tax based on the rates of article 17 paragraph (1) letter a. This is certainly a good choice for taxpayers who are disadvantaged if they use PP-23/2018, so that taxpayers can still use bookkeeping or NPPN rules in the imposition of income tax.

The presumptive tax scheme in PP-46/2013 provides a separate space for taxpayers to avoid tax (Bird and Wallace, 2004). The political economy created by the presumptive tax almost guarantees that the tax burden enjoyed by those in the scheme is quite profitable and makes it an attractive place to survive. This phenomenon has also been studied by Nurfauzi et al. (2019) by using the bunching estimation method. His research concluded that companies would respond by choosing which way would give them a lower tax burden. Companies will withhold their turnover when the presumptive tax scheme provides them with incentives. Meanwhile, when the incentive is not applied, the company will report its sales are close to its optimal capacity so it is not included in PP-46/2013.

Bird and Wallace (2004) state that the main drawback of presumptive tax is the absence of an explicit plan to push taxpayers out of presumptive tax into a general regime. This is what happened in PP$46 / 2013$, MSMEs can use it for a permanent time as long as the gross revenue has not exceeded Rp. 4.8 billion. Low tariffs and an easy system have the potential to create reluctance for MSMEs to start maintaining good books and comply with the general income tax system. As a result, efforts to erode the informality of the tax system are difficult to realize.

In order to overcome this problem, the government issued PP-23/2018 which also regulates a certain period of time for the application of final income tax for certain taxpayers. The duration is between three to seven years, which is differentiated by MSME managers. The existence of regulations for a certain period of time is an expectation that MSMEs are not always in the informal sector which tends to manage their business in a simple way. Due to the existence of a certain period of time, MSMEs are forced to use the general regime after that period is over, namely the imposition of income tax based on the tariffs of Article 17 paragraph (1) letter a.

The general provisions in the Income Tax Law still adopt the global tax system, namely taxes are imposed based on net income. Meanwhile, PP-23/2018 focuses more on the schedular tax system. The schedular tax system itself is usually used to tax income derived from capital such as dividends, interest, and rent for land and buildings. This income is usually passive and almost certainly makes a profit (Kristiaji \& Mukarromah, 2020). However, MSME income is active income and there is a possibility of loss. That is, the appropriate tax imposition on MSMEs is based on their net income. Therefore, this regulation period can also restore taxation in accordance with the global tax system.

The issue of supervision is also still an important matter to be discussed. After that period is over, MSMEs will return to the general regime. This will be a challenge for DGT to monitor the large number of them. Based on 2019 data, the number of account representatives at DGT is 10,918 employees. When juxtaposed with the total registered taxpayers, each account representative must supervise approximately 4,200 taxpayers. The high workload and the existence of revenue targets mean that supervision is usually prioritized for taxpayers who have a high risk of non-compliance, available data, and high tax potential. Unfortunately, MSMEs often do not meet the data and potential requirements (Suyani, 2017). This is an area that the government needs to pay attention to in implementing this time period regulation. This means that the time period given is not only a learning period for MSMEs, but also a time for DGT to build a better monitoring system. Therefore, a certain period of time must be a concern for both the taxpayer and the DGT.

MSMEs in general still have not made adequate financial reports. One of the main causes is the inability of MSMEs to carry out good bookkeeping administration so that net income is difficult to know with certainty. PP-23/2018 is only the beginning of the imposition of Income tax to MSMEs for a certain period of time. Through PP-23/2018, MSMEs are encouraged to prepare books to calculate their tax obligations. The remaining task is how to optimize the role of the government, especially the DGT, in conducting dissemination and assistance related to the bookkeeping system and aspects of tax administration. These various efforts are actually to ensure that MSMEs that are under the presumptive tax regime can prepare to enter the general taxation regime within a predetermined period of time.

\section{CONCLUSION}

Micro, Small, and Medium Enterprises are an essential sector for Indonesia. The high contribution to GDP and employment has enabled them as a driving force in the economy. However, MSMEs in Indonesia are still managed in a simple manner and most of them are still in informal sectors. Therefore, the imposition of income tax on MSMEs is still concerned with the simplicity aspect through PP-23/2018 which is reflected in the imposition of final income tax based on gross turnovers. However, the results stated that the imposition of final income tax on PP-23/2018 may result in a higher tax burden for corporate taxpayers with lower profit margins and a lower tax burden for corporate taxpayers with the higher ones. The result also applies to individual taxpayers. In addition, the absence of a lower limit means that individual taxpayers with a gross turnover and a profit margin at a certain level should not be taxed. Even so, the reduction in only one tax rate under PP-23/2018 provides a greater opportunity to obtain incentives than its previous regulation, namely PP-46/2013. 
The convenience of final income tax imposition and incentives provided in regulation PP-46/2013 can incentivizes taxpayers to stay in the informal sector. As a result, efforts to erode the informality of the tax system are difficult to realize. The change in the policy direction emphasizes the objective to reduce informality in MSMEs. PP-23/2018 allows MSMEs to use bookkeeping they are given a certain period of time to learn the bookkeeping system and the tax administration system. Furthermore, a certain period of time can be a warning sign to the DGT to improve its supervision system due to a large number of MSMEs. In addition, DGT also needs to conduct dissemination and assistance regarding bookkeeping system and tax administration aspects to ensure that MSMEs under the presumptive tax scheme can prepare to enter the general taxation regime within a predetermined period of time.

\section{REFERENCES}

Aditya, C. (2020). The Presumptive Tax Regime on Micro, Small and Medium Enterprises in Indonesia. Jurnal IImiah Indonesia, 5(6), 50-63.

Aneswari, Y. R. (2018). Membongkar Imperialisme dalam Kebijakan Pajak Usaha Mikro Kecil dan Menengah (UMKM). InFestasi, 14(1), 1-10.

Anggara, S. (2016). Hukum Administrasi Perpajakan. Pustaka Setia.

Badan Pusat Statistik. (2019). Potensi Peningkatan Kinerja Usaha Mikro Kecil.

Bird, R. M., \& Wallace, S. (2004). Is it Really so Hard to Tax the Hard-to-Tax? The Context and Role of Presumptive Taxes. 8555(4), 121-158.

Direktorat Jenderal Pajak. (2019). Sinergi Menuju Kemandirian Ekonomi Nasional. Laporan Tahunan 2018 Direktorat Jenderal Pajak.

Eissa, N., \& Zeitlin, A. (2017). Final report Fiscal impacts of a presumptive tax for microenterprises in Rwanda. International Growth Centre

Endrianto, W. (2015). Prinsip Keadilan dalam Pajak atas UMKM. Binus Business Review, 6(2), 298-308.

Hadiprajitno, P. T. B., \& Zulaikha. (2016). Presumptive Taxation Scheme : Dampaknya Terhadap Beban dan Kepatuhan Sukarela Wajib Pajak. Simposium Nasional Akuntansi XIX, 1-24.

Ibrahim, S. (2013). Pengenaan PPh Final untuk Wajib Pajak dengan Peredaran Bruto Tertentu, Sebuah Konsep Kesederhanaan Pengenaan PPh untuk Meningkatkan Voluntary Tax Compliance. Pusat Kebijakan Pendapatan Negara-Badan Kebijakan Fiskal, 1-10.

Kabinga, M. (2016). Principles of Taxation. Introduction to the Project "Tax Justice \& Poverty.

Kristiaji, B. B., \& Mukarromah, A. (2020). Meninjau Konsep dan Relevansi PPh Final di Indonesia. DDTC Working Paper 2220.

Nurfauzi, E. A., Nuryakin, C., \& Putra, B. C. (2019). Firms Bunching Response to Indonesian Income Tax Threshold. Journal of Economics and Policy, 12(1), 153-167.
Pakpahan, Y. E. (2015). Pengaruh Pemahaman Akuntansi, Pemahaman Ketentuan Perpajakan dan Transparansi Dalam Pajak Terhadap Kepatuhan Wajib Pajak Badan. JOM FEKON, 2(1), 1-15.

Pemerintah Republik Indonesia. (2018). Peraturan Pemerintah Nomor 23 Tahun 2018 tentang Pajak Penghasilan atas Penghasilan Dari Usaha yang Diterima atau Diperoleh Wajib Pajak yang Memiliki Peredaran Bruto Tertentu. Jakarta: Sekretariat Negara.

Purwanto. (2014). Pajak Penghasilan. Pusat Pendidikan dan Pelatihan Pajak.

Repetti, J., \& McDaniel, P. (1993). Horizontal and Vertical Equity: The Musgrave/Kaplow Exchange. Florida Tax Review, 1(10), 607-622.

Samsu. (2017). Metode penelitian: teori dan aplikasi penelitian kualitatif, kuantitatif, mixed methods, serta research \& development. Pusat Studi Agama dan Kemasyarakatan (PUSAKA).

Smith, A (1776). The Wealth of Nations. Book 4: Systems of Political Economy. Elecbook Classic

Stotsky, J. (1999). The Choice of Taxable Unit. Tax Policy Handbook (pp. 124-129).

Suyani, E. (2017). Analisis Skema Presumptive untuk Penghitungan Pajak Penghasilan Wajib Pajak UMKM di Indonesia. Jurnal Info Artha, 1(2), 139149.

Verberne, J. (2018). Taxation and the Informal Business Sector in Uganda. Journal of Accounting and Taxation, 1-21.

Zulvina, S., Ariwibowo, I., \& Bandiyono, A. (2017). Pengantar Hukum Pajak. Politeknik Keuangan Negara STAN 